\title{
Association between emotional intelligence and empathy among medical students: a single center cross-sectional study, Brazil, 2019
}

\author{
Associação entre inteligência emocional e empatia em estudantes de Medicina: estudo transversal unicêntrico, Brasil, 2019 \\ Janaína Teixeira Nunes Silva' (1D | teixjana@yahoo.com.br

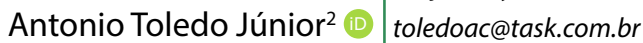

\begin{abstract}
Introduction: Emotional intelligence (EI) and empathy are two essential skills for person-centered Medicine.

Objectives: To evaluate the association between El and empathy and to assess whether sociodemographic factors and year at the medical school influence the level of El and empathy.

Methods: Cross-sectional study carried out in medical students from a private educational institution in the city of São João del-Rei, Minas Gerais, Brazil. El levels were assessed using the Schutte Self-report Emotional Intelligence Test and empathy levels were assessed using the Jefferson Scale of Empathy (student version). All volunteers signed the Informed Consent Form before inclusion in the study. The statistical analysis used mean values, standard deviation, frequency distribution, Student's t test, Pearson's correlation, and linear regression. A significance level of 0.05 was considered.

Results: From August 5 to 30, 2019, 193 volunteers, corresponding to $85.8 \%$ of the total population, agreed to participate in the study. The total El $(129.8 \pm 13.3)$ and empathy $(121.2 \pm 11.6)$ observed scores were high. El scores were influenced only by age $\left(p_{\text {adjusted }}=0.018\right)$. Students attending more advanced semesters had higher total empathy scores $\left(p_{\text {adjusted }}=0.013\right)$. Students whose parents did not have a higher education degree also had a higher total empathy score $\left(p_{\text {adiusted }}=0.031\right)$. A moderate positive correlation was observed between the total El and empathy scores $(\boldsymbol{\rho}=0.304, p<0.001)$ and between the total empathy score and the El domain Managing Others' Emotions $(\boldsymbol{\rho}=0.300, p<0.001)$. A weak positive correlation was also observed between the total El score and most of the empathy domains.
\end{abstract}

Conclusion: A positive correlation between emotional intelligence and empathy was observed. The age influenced El and the year of medical school and parental schooling influenced empathy.

Keywords: Medical Education; Medical Students; Empathy; Emotional Intelligence.

\section{RESUMO}

Introdução: A inteligência emocional (IE) e a empatia são duas habilidades essenciais para a medicina centrada na pessoa.

Objetivos: Avaliar a associação entre IE e empatia e verificar se fatores sociodemográficos e o tempo de curso influenciam os seus níveis.

Métodos: Trata-se de estudo transversal realizado com estudantes de Medicina de uma instituição privada de ensino da cidade de São João del-Rei, Minas Gerais, Brasil. Os níveis de IE foram avaliados por meio do Teste de Autoavaliação de Inteligência Emocional de Schutte e os níveis de empatia, pela Escala de Empatia de Jefferson (versão para estudante). Todos os voluntários assinaram o Termo de Consentimento Livre e Esclarecido antes da inclusão no estudo. A análise estatística utilizou a média, o desvio padrão, a distribuição de frequência, o teste t de Student, a correlação de Pearson e a regressão linear. Foi considerado o nível de significância de 0,05.

Resultados: De 5 a 30 de agosto de 2019, 193 voluntários, que correspondiam a 85,8\% da população total, concordaram em participar do estudo. Os escores totais observados de IE $(129,8 \pm 13,3)$ e empatia $(121,2 \pm 11,6)$ foram elevados. O escore total de IE foi influenciado pela idade $\left(p_{\text {ajustado }}=0,018\right)$. Os alunos de períodos mais avançados apresentaram escore total de empatia mais alto $\left(p_{\text {ajustado }}=0,013\right)$. Os estudantes cujos pais não possuíam curso superior também apresentaram escore total de empatia mais elevado $\left(p_{\text {ajustado }}=0,031\right)$. Observou-se correlação positiva moderada entre os escores totais de IE e de empatia $(\boldsymbol{\rho}=0,304, p<0,001)$, e entre o escore total de empatia e o domínio Manejo das Emoções dos Outros de IE ( $\rho=0,300, p<0,001)$. Observou-se também correlação positiva fraca entre o escore total de IE e a maioria dos domínios de empatia.

Conclusão: Observou-se correlação positiva entre IE e empatia. A IE foi influenciada pela idade; e a empatia, pelo período do curso e pela escolaridade dos pais.

Palavras-chave: Educação Médica; Estudantes de Medicina; Empatia; Inteligência Emocional.

${ }^{1}$ Centro Universitário Presidente Tancredo de Almeida Neves, São João del-Rei, Minas Gerais, Brazil.

2 Universidade José do Rosário Vellano, Belo Horizonte, Minas Gerais, Brazil.

Chief Editor: Daniela Chiesa

Associate Editor: Daniela Chiesa

Received on 02/27/20; Accepted on 01/12/21.

Evaluated by double blind review process. 


\section{INTRODUCTION}

In the medical profession, emotional intelligence and empathy are key concepts for organizing the interpersonal and communication skills ${ }^{1,2}$. Both emotional intelligence and empathy are the basis for the capacity to recognize emotions and affective messages in others, build a therapeutic alliance, effectively communicate with patients and their family members and create a good doctor-patient relationship. For this reason, these concepts have currently become so important, when compassionate, humanitarian and quality health care is sought ${ }^{3}$.

The idea of emotional intelligence has its roots in the concept of social intelligence, first described by Thorndike in 1920, who defined that intelligence as "the capacity to perceive internal states and one's own reasons and behaviors, as well as the others', and to act on them appropriately based on that information"4. Salovey and Mayer were the first to suggest the name emotional intelligence (EI) to refer to people's ability to deal with their emotions and defined El as "a subset of social intelligence, which comprises the capacity to monitor people's feelings and emotions, of one's own and others', to discriminate between them and use that information to guide thoughts and actions"4.

In Medicine, El has been considered very important, especially regarding the careful management of emotions, which is necessary in the practice and daily care of patients ${ }^{5}$. During their training, medical students witness situations of pain and suffering on a daily basis, experienced by their patients and family members, and must be able to face these situations, helping them, but at the same time understanding and differentiating the pain of the other from their own pain. Therefore, it is important that during their training they are able understand the emotions and feelings of the other, show that they understand them and how they understand them, but also that they can perceive, feel and experience these emotions and feelings without being overwhelmed by them, while always maintaining dominance and control of their own emotions ${ }^{1}$.

Empathy is another important skill for medical practice. According to its modern concept, empathy is the capacity to understand and share the feelings of others ${ }^{6}$. Hojat defined empathy in the health care context as being predominantly a cognitive emotional attribute that involves understanding the patient's pain, experiences, interests and perspectives, combined with the capacity to communicate this understanding and the ability to help ${ }^{7}$.

Patients see doctors who have more empathy as better professionals. A doctor can be very competent in clinical diagnosis and will still be considered ineffective if they lose the connection between patient satisfaction, adherence to medical instructions and empathy ${ }^{8}$.

El and empathy are related but are distinct constructs. Among the different models of El, the Bar-On and Goleman models consider empathy as one of its basic components, suggesting a very close association between these two constructs ${ }^{1}$. Salovey and Mayer, on the other hand, consider empathy as a central characteristic of El behavior and empathic response as an El component ${ }^{4}$. Irrespective of the model, there is a consensus that El comprehends the way people differ in their emotional capacities, both intrapersonal (mood regulation, stress management and perception of one's own emotions) and interpersonal (social skills, perception of others' emotions). Therefore, empathy overlaps with interpersonal El and encompasses the capacity to be aware of and understand other people's feelings ${ }^{9}$.

Some studies have simultaneously assessed emotional intelligence and empathy, but not the association between the two constructs. Austin et al. evaluated 273 medical students in the first, second and fifth years of medical school, aiming at comparing the levels of empathy, assessing gender differences in empathy and $\mathrm{El}$ and investigating whether El and empathy were related to academic success. Higher levels of empathy were observed among women. Sparse associations were found between academic performance and $\mathrm{El}$ and there was no association between academic performance and empathy ${ }^{9}$.

Studies that specifically assessed the association between El and empathy are scarce. A study carried out in Japan between 2008 and 2011 evaluated 415 students starting medical school, who were asked to answer questionnaires regarding El, empathy and personality traits. The results indicated a weak positive correlation between El and empathy ${ }^{6}$. A cross-sectional study carried out with 329 nursing students from a university in Iran showed a strong positive correlation between empathy and El, indicating that the increase in emotional intelligence scores is directly associated with the increase in empathy scores ${ }^{10}$.

In recent years, it has been recognized in the medical literature that interpersonal skills and the management of emotions are very important for doctors, having a primary role in the quality of doctor-patient relationship. Considering that these are skills, they can be learned, trained and improved throughout the medical program, aiming at the formation of more humanistic doctors and being person-centered care. No study conducted in Brazil that assessed the association between emotional intelligence and empathy in medical students was identified in the literature review. Given this reality, the main objective of this study was to assess the association between emotional intelligence and empathy in this population. 


\section{METHODS}

A cross-sectional study was carried out in medical students at Centro Universitário Presidente Tancredo de Almeida Neves (UNIPTAN), which is a private educational institution, located in the city of São João del-Rei, state of Minas Gerais, Brazil. UNIPTAN was founded in 2000, and the medical program was created in 2015 and follows a mixed teaching methodology. The target population consisted of all students enrolled in the second semester of 2019.

The inclusion criteria were: to be regularly enrolled in the medical program in the second semester of 2019 and to sign the Informed Consent Form (ICF). Students were excluded if they: participated in any research using one of the instruments utilized in this study in the last 2 years, did not sign the ICF, or did not complete the questionnaire. All students in the fourth and fifth semesters were excluded for having participated in a study using the questionnaire for the assessment of the El in 2018. In the second semester of 2019, the program did not have a seventh semester, as there was no selection process corresponding to that semester.

The potential population, therefore, consisted of 225 students, 140 (62.2\%) women and 85 (37.8\%) men. A nonprobabilistic convenience sample was used. All students who met the inclusion criteria were invited to participate. The students were approached by the researchers at the end of a class and received detailed explanations about the study, clarifying doubts and explaining that participation would be totally voluntary. The researchers made it clear that volunteers could withdraw from participation at any time and their privacy would be fully respected and the confidentiality of their personal information would be guaranteed. Students who agreed to participate signed the ICF, received the questionnaire, filled it out and returned it to a researcher.

\section{Data collection}

Empathy was assessed using the students version of the Jefferson Scale of Empathy (JSE-S) ${ }^{3,11}$ and El by the Schutte Selfreport Emotional Intelligence Test (SSREIT) ${ }^{12,13}$.

The JSE-s is a 20-item self-completed instrument designed to measure empathy in the context of patient care and is used worldwide as a measure of empathy in medical students. Since students have contact with patients since the first year of medical school in basic health units and under the supervision of Family and Community Health Doctors, it was decided to include students in the basic cycle of medical program. The items are answered according to a seven-point Likert scale, ranging from 1 "strongly disagree" to 7 "strongly agree". The answers to questions $1,3,6,7,8,11,12,14,18$ and 19 have a reverse score (strongly agree $=1$, strongly disagree $=7$ ) and their values must be inverted before the final score is calculated ${ }^{11}$. The values obtained from each question are added and the final score represents the empathy score. The global score ranges from 20 to 140 points. Higher scores indicate higher levels of empathy. In addition to the total score, the questionnaire assesses three domains ${ }^{3}$ : Perspective Taking (seven items - 7 to 49 points), Compassionate Care (11 items - 7 to 77 points) and the Ability to Stand in the Patient's Shoes (two items - 7 to 14 points).

The SSREIT was developed and validated as an instrument to measure the level of El based on the original instrument by Salovey and Mayer ${ }^{12}$. It is a 33-item, self-administered questionnaire, which uses a five-point Likert scale, in which 1 means "strongly disagree" and 5 means "strongly agree". The total score obtained is calculated by adding the reverse score on items 5,28 and 33 and the original values from other items. The global score ranges from 33 to 165 . Higher scores indicate higher levels of El. This scale has four domains: Perception of Emotion (10 items - 10 to 50 points), Managing Own Emotions (9 items - 9 to 45 points), Managing Others' Emotions ( 8 items - 8 to 40 points) and Utilization of Emotion ( 6 items - 6 to 30 points) ${ }^{13}$.

The main outcomes were the global empathy and $\mathrm{EI}$ scores and the secondary outcomes were the domain scores for each of the scales. The independent variables were gender, age, parental schooling level, previous higher education degree, history of severe personal or family illness, self-reported history of depression or mental illness, program semester and intended medical specialty (clinical or surgical).

\section{Statistical Analysis}

The database was created using Microsoft $^{\circ}$ Excel $^{\circ}$ (Microsoft, USA) and statistical analysis was performed using IBM $^{\circ}$ SPSS Statistics v. 19 (IBM, USA). The total scores and the scores of the different domains in the two scales were calculated for the purposes of statistical analysis. In the descriptive analysis, measures of central tendency for continuous variables and frequency distribution for categorical variables were used. Levene's test was used to verify the homogeneity of continuous variable distribution. Student's t test and ANOVA were used in comparative analysis. Linear regression was performed to analyze which sociodemographic and personal variables were actually associated with the differences observed in the El and empathy total scores. Variables with $p \leq 0.25$ in comparative analysis were included in the multivariate analysis. The gender variable was included in all analyses due to its importance in relation to $\mathrm{El}$ and empathy. Pearson's correlation test was used to compare age and levels of empathy and El and between empathy and $\mathrm{El}$, considering the total score and the different domains. The level of statistical significance was set at 0.05 . Pearson's test was interpreted according to Cohen's 
recommendations ${ }^{14}$ :

- $\quad \rho$ between 0.10 and 0.29 - weak correlation;

- $\quad \rho$ between 0.30 and 0.49 - moderate correlation; and

- $\rho$ between 0.50 and 1 - strong correlation.

\section{Ethical Aspects}

This study is in accordance with the current version of the Declaration of Helsinki, Resolution 466/2012 of CONEP and its updates and Resolution 510/2016 of CNS and was approved by the Research Ethics Committee of Universidade José do Rosário Vellano (Opinion 3,361,657).

\section{RESULTS}

From August 5 to 30, 2019, a total of 193 volunteers agreed to participate in the research. This sample corresponded to $85.8 \%$ of the total population of students (Figure 1). It took them 15 to 20 minutes to complete the questionnaire.

Table 1 shows the sociodemographic and personal characteristics of the 193 students. There was a predominance of female (126-65.3\%) and single (186 - 96\%) students. The second semester contributed with the highest number of students (42 $21.8 \%$ ) and the eighth semester with the lowest (20 - 10.4\%). Most students had both parents with a high education degree (88 $45.6 \%), 61$ (31.6\%) had only one of them with a high education degree and 42 (21.8\%) had neither with a high education degree. Fourteen students had a previous higher education degree (7.3\%). Regarding the intended specialty, the majority indicated a clinical specialty (105 - 54.4\%). Forty-two students (21.8\%) reported the existence of some severe illness in the family. Only seven (3.6\%) reported having any serious illness and 57 (29.5\%) self-reported the existence of a previous mental disorder. The mean age of the participants was $22.6 \pm 4.1$ years, ranging from 17 to 40 years. Most students (181 - 93.8\%) were aged up to 30 years old.

Figure 1. Volunteer recruitment flowchart

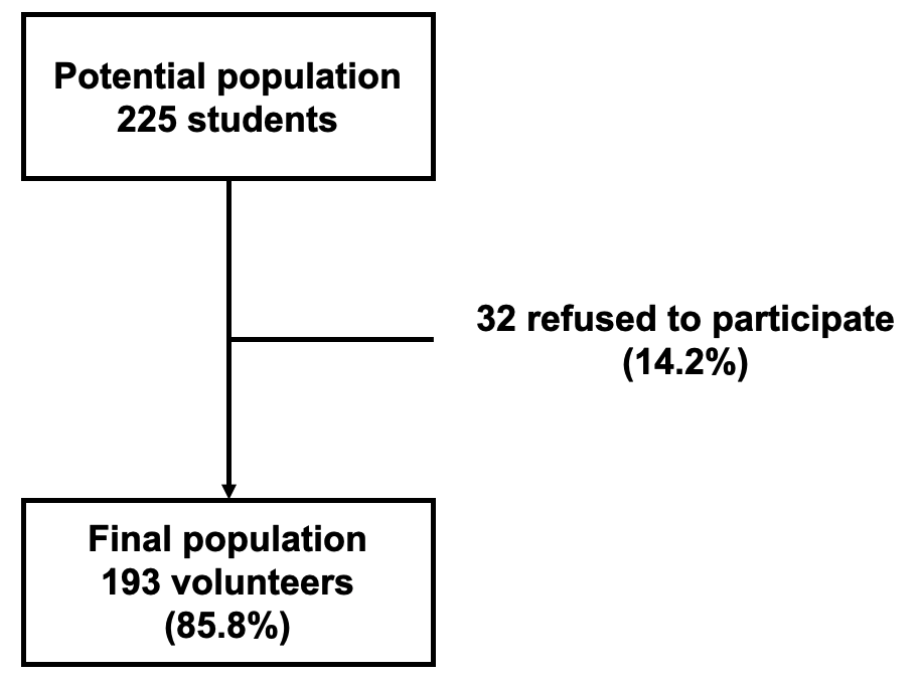

The mean total emotional intelligence score was 129.8 \pm 13.3 (78.7\% of the possible total), with the mean of the Perception of Emotion domain being $36.6 \pm 5.2$ (73.2\% of the total), Managing Own Emotion $37.1 \pm 5.3$ (82.4\%), Managing Others' Emotions $31.7 \pm 4.1$ (79.3\%) and Use of Emotion 24.3 \pm 3.3 (81.0\%). The mean total empathy score was $121.2 \pm 11.6$ ( $86.5 \%$ of the total possible), with the mean of the Perspective Taking domain being $41.6 \pm 5.1$ (84.9\%), Compassionate Care, $70.9 \pm 7.2(92.1 \%)$ and the Ability to Stand in the Patient's Shoes, $8.8 \pm 3.1$ (62.9\%) (Table 2).

Table 1. Personal and sociodemographic characteristics of the 193 volunteers

\begin{tabular}{|c|c|c|c|}
\hline Variable & & $\mathbf{N}$ & $\%$ \\
\hline \multirow{2}{*}{ Gender } & Female & 126 & 65.3 \\
\hline & Male & 67 & 34.7 \\
\hline \multirow{2}{*}{ Marital status } & Single & 186 & 96.4 \\
\hline & Married/Others & 7 & 3.6 \\
\hline \multirow{6}{*}{ Program semester* } & $1^{\text {st }}$ & 40 & 20.7 \\
\hline & $2^{\text {nd }}$ & 42 & 21.8 \\
\hline & $3^{\text {rd }}$ & 33 & 17.1 \\
\hline & $6^{\text {th }}$ & 35 & 18.1 \\
\hline & $8^{\text {th }}$ & 20 & 10.4 \\
\hline & $9^{\text {th }}$ & 23 & 11.9 \\
\hline \multirow{4}{*}{$\begin{array}{l}\text { Parental schooling } \\
\text { level }\end{array}$} & $\begin{array}{l}\text { Neither has a high } \\
\text { education degree }\end{array}$ & 42 & 21.8 \\
\hline & $\begin{array}{l}\text { One has a high } \\
\text { education degree }\end{array}$ & 61 & 31.6 \\
\hline & $\begin{array}{l}\text { Both have a high } \\
\text { education degree }\end{array}$ & 88 & 45.6 \\
\hline & No information & 2 & 1.0 \\
\hline \multirow{2}{*}{ Previous degree } & No & 179 & 92.7 \\
\hline & Yes & 14 & 7.3 \\
\hline \multirow{3}{*}{$\begin{array}{l}\text { Preferred medical } \\
\text { specialty }\end{array}$} & Clinical specialty & 105 & 54.4 \\
\hline & Surgical specialty & 82 & 42.5 \\
\hline & No information & 6 & 3.1 \\
\hline \multirow{3}{*}{$\begin{array}{l}\text { Has a case of } \\
\text { severe disease in } \\
\text { the family }\end{array}$} & No & 148 & 76.7 \\
\hline & Yes & 42 & 21.8 \\
\hline & No information & 3 & 1.5 \\
\hline \multirow{2}{*}{$\begin{array}{l}\text { Has a personal } \\
\text { severe disease }\end{array}$} & No & 186 & 96.4 \\
\hline & Yes & 7 & 3.6 \\
\hline \multirow{3}{*}{$\begin{array}{l}\text { Previous mental } \\
\text { disorder }\end{array}$} & No & 135 & 69.9 \\
\hline & Yes & 57 & 29.5 \\
\hline & No information & 1 & 0.6 \\
\hline Age & & $\begin{array}{c}22.6 \\
\text { (mean) }\end{array}$ & $4.1(\mathrm{SD})$ \\
\hline
\end{tabular}

* in the second semester of 2019, the program did not have a seventh semester, as there was no selection process corresponding to that semester. $\mathrm{SD}=$ standard deviation 
Table 3 shows the results of the bivariate and multivariate analyses related to the total emotional intelligence score and the sociodemographic and personal variables. Only age showed an association with El levels. An increase in El levels was observed with increasing age $\left(p_{\text {adjusted }}=0.018\right)$.

When assessing empathy, a statistically significant difference was observed only in relation to the program semester and parental schooling level. Students from more advanced

Table 2. Total score of emotional intelligence and empathy and their different domains in the 193 volunteers

\begin{tabular}{lccc}
\hline \multicolumn{1}{c}{ Emotional Intelligence } & Score interval & Mean & SD \\
\hline Total score & $33-165$ & 129.8 & 13.3 \\
Perception of Emotion & $10-50$ & 36.6 & 5.2 \\
Managing Own Emotion & $9-45$ & 37.1 & 5.3 \\
Managing Others' Emotions & $8-40$ & 31.7 & 4.1 \\
Use of Emotion & $6-30$ & 24.3 & 3.3 \\
\hline \multicolumn{1}{c}{ Empathy } & Score interval & Mean & SD \\
\hline Total score & $20-140$ & 121.2 & 11.6 \\
Perspective Taking & $7-49$ & 41.6 & 5.1 \\
Compassionate Care & $11-77$ & 70.9 & 7.2 \\
Ability to Stand in the & $2-14$ & 8.8 & 3.1 \\
Patient's Shoes & & & \\
\hline
\end{tabular}

SD: standard deviation. semesters had a higher total empathy score $\left(p_{\text {adjusted }}=0.013\right)$. Volunteers whose parents did not have a higher education degree showed higher empathy levels than those who had at least one parent with a high education degree (125.0 \pm 9.37 versus $120.3 \pm 11.83 ; \mathrm{p}_{\text {adjusted }}=0.031$ ), as shown in Table 4 .

Pearson's correlation showed a positive association between total El and empathy scores and their domains (Table 5). There was also a positive and statistically significant association between all domains of El and empathy, with the exception of the domain Use of Emotion of El with the Compassionate Care and Ability to Stand in the Patient's Shoes empathy domains. Although the correlations are statistically significant, only the associations between the total score and between the total empathy score and the domain Managing Others' Emotions of El showed a moderate correlation $(\rho \geq 0.30)$, as shown in Figure 2 .

\section{DISCUSSION}

The main objective of this study was to evaluate the association between emotional intelligence and empathy in medical students from the UNIPTAN. The influence of sociodemographic and personal factors, including the program semester, on El and empathy was also assessed. The results showed that, in general, the El and empathy scores were high, about $80.0 \%$ of the total possible points.

Table 3. Bivariate and multivariate analysis between total emotional intelligence score and sociodemographic and personal data of the 193 volunteers

\begin{tabular}{|c|c|c|c|c|c|c|}
\hline Variable & & $\mathbf{n}$ & Mean & SD & $\mathbf{p}_{\text {crude }}{ }^{*}$ & $\mathbf{p}_{\text {adjusted }}$ \\
\hline Program semester $* * *$ & & 193 & --- & --- & $0.216^{* *}$ & 0.811 \\
\hline $\operatorname{Age}^{* * *}$ & & 193 & --- & --- & $0.041^{* *}$ & 0.018 \\
\hline \multirow{2}{*}{ Gender ${ }^{* * *}$} & Female & 126 & 129.6 & 13.3 & 0.740 & 0.948 \\
\hline & Male & 67 & 130.2 & 13.3 & & \\
\hline \multirow{2}{*}{ Marital status *** } & Single & 186 & 130.0 & 13.1 & 0.240 & 0.074 \\
\hline & Married/Others & 7 & 124.0 & 17.3 & & \\
\hline \multirow{2}{*}{ Parental schooling level } & Neither with high education degree & 42 & 130.0 & 14.1 & 0.833 & --- \\
\hline & $\geq 1$ with High education degree & 149 & 129.5 & 13.0 & & \\
\hline \multirow{2}{*}{$\begin{array}{l}\text { Previous high education } \\
\text { degree }\end{array}$} & No & 179 & 129.5 & 13.4 & 0.234 & --- \\
\hline & Yes & 14 & 133.9 & 10.1 & & \\
\hline \multirow[t]{2}{*}{ Intended specialty type } & Clinical specialty & 105 & 130.1 & 13.3 & 0.861 & --- \\
\hline & Surgical specialty & 82 & 129.7 & 13.5 & & \\
\hline \multirow{2}{*}{$\begin{array}{l}\text { Has a case of severe disease in } \\
\text { the family }\end{array}$} & No & 148 & 129.6 & 13.2 & 0.513 & --- \\
\hline & Yes & 42 & 131.1 & 13.7 & & \\
\hline \multirow{2}{*}{ Has a personal severe disease } & No & 186 & 129.6 & 13.3 & 0.362 & --- \\
\hline & Yes & 7 & 134.3 & 13.4 & & \\
\hline \multirow{2}{*}{ Previous mental disorder*** } & No & 135 & 130.5 & 12.3 & 0.250 & 0.208 \\
\hline & Yes & 57 & 128.1 & 15.4 & & \\
\hline
\end{tabular}

* Student's t test; ${ }^{* *}$ ANOVA; Levene's test $>0.05$ for all variables; ${ }^{* * *}$ variables included in the multivariate analysis. SD - standard deviation. 
Table 4. Bivariate and multivariate analysis between the total empathy score and sociodemographic and personal data of the 193 volunteers

\begin{tabular}{|c|c|c|c|c|c|c|}
\hline Variable & & $\mathbf{n}$ & Mean & SD & $\mathbf{p}_{\text {crude }}{ }^{*}$ & $\mathbf{p}_{\text {adjusted }}$ \\
\hline Program semester*** & & 193 & --- & --- & $<0.001 * *$ & 0.013 \\
\hline $\operatorname{Age}^{* * *}$ & & 193 & --- & --- & $0.850^{* *}$ & --- \\
\hline \multirow{2}{*}{ Gender } & Female & 126 & 122.2 & 11.0 & 0.122 & 0.109 \\
\hline & Male & 67 & 119.5 & 12.5 & & \\
\hline \multirow{2}{*}{ Marital status } & Single & 186 & 121.2 & 11.8 & 0.856 & --- \\
\hline & Married/Others & 7 & 122.0 & 3.7 & & \\
\hline \multirow{2}{*}{ Parental schooling level ${ }^{* * *}$} & Neither with high education degree & 42 & 125.0 & 9.4 & 0.018 & 0.031 \\
\hline & $\geq 1$ with high education degree & 149 & 120.3 & 11.8 & & \\
\hline \multirow{2}{*}{$\begin{array}{l}\text { Previous high education } \\
\text { degree }\end{array}$} & No & 179 & 121.4 & 11.5 & 0.444 & --- \\
\hline & Yes & 14 & 118.9 & 13.3 & & \\
\hline \multirow{2}{*}{ Intended specialty type } & Clinical specialty & 105 & 121.5 & 12.4 & 0.602 & --- \\
\hline & Surgical specialty & 82 & 120.6 & 10.8 & & \\
\hline \multirow{2}{*}{$\begin{array}{l}\text { Has a case of severe } \\
\text { disease in the family }\end{array}$} & No & 148 & 121.5 & 11.4 & 0.390 & --- \\
\hline & Yes & 42 & 119.8 & 12.4 & & \\
\hline \multirow{2}{*}{$\begin{array}{l}\text { Has a personal severe } \\
\text { disease }\end{array}$} & No & 186 & 121.1 & 11.7 & 0.540 & --- \\
\hline & Yes & 7 & 123.9 & 9.1 & & \\
\hline \multirow{2}{*}{ Previous mental disorder } & No & 135 & 121.2 & 11.2 & 0.955 & --- \\
\hline & Yes & 57 & 121.3 & 12.7 & & \\
\hline
\end{tabular}

*Student's t test; ${ }^{* *}$ ANOVA; Levene's test $>0.05$ for all variables; ${ }^{* * *}$ variables included in the multivariate analysis. SD - standard deviation.

Table 5. Correlation between emotional intelligence total score and its domains and the total empathy score and its domains in 193 volunteers

\begin{tabular}{ccc}
\hline Total score of emotional intelligence & $\boldsymbol{\rho}$ & $\mathbf{p}^{*}$ \\
\hline Total empathy score & 0.304 & $\mathbf{0 . 0 0 0}$ \\
Perspective Taking & 0.236 & $\mathbf{0 . 0 0 1}$ \\
Compassionate Care & 0.222 & $\mathbf{0 . 0 0 2}$ \\
Ability to Stand in the Patient's Shoes & 0.236 & $\mathbf{0 . 0 0 1}$ \\
\hline Perception of Emotion & $\boldsymbol{\rho}$ & $\mathbf{p}^{*}$ \\
\hline Total empathy score & 0.230 & $\mathbf{0 . 0 0 1}$ \\
Perspective taking & 0.143 & $\mathbf{0 . 0 4 7}$ \\
Compassion & 0.168 & $\mathbf{0 . 0 1 9}$ \\
Capacity to put oneself in the other's place & 0.237 & $\mathbf{0 . 0 0 1}$ \\
\hline Managing Own Emotions & $\boldsymbol{\rho}$ & $\mathbf{p}$ \\
\hline Total empathy score & 0.189 & $\mathbf{0 . 0 0 9}$ \\
Perspective Taking & 0.145 & $\mathbf{0 . 0 4 4}$ \\
Compassionate Care & 0.133 & $\mathbf{0 . 0 6 5}$ \\
\hline Ability to Stand in the Patient's Shoes & 0.161 & $\mathbf{0 . 0 2 5}$ \\
\hline Managing Others' Emotions & $\boldsymbol{\rho}$ & $\mathbf{p}$ \\
\hline Total empathy score & 0.300 & $\mathbf{0 . 0 0 0}$ \\
Perspective Taking & 0.251 & $\mathbf{0 . 0 0 0}$ \\
Compassionate Care & 0.245 & $\mathbf{0 . 0 0 1}$ \\
\hline Ability to Stand in the Patient's Shoes & 0.145 & $\mathbf{0 . 0 4 4}$ \\
\hline & & \\
\hline & &
\end{tabular}

Continue...
Table 5. (Continuation) Correlation between emotional intelligence total score and its domains and the total empathy score and its domains in 193 volunteers

\begin{tabular}{ccc}
\hline Use of Emotion & $\boldsymbol{\rho}$ & $\mathbf{p}^{*}$ \\
\hline Total empathy score & 0.183 & $\mathbf{0 . 0 1 1}$ \\
Perspective Taking & 0.177 & $\mathbf{0 . 0 1 4}$ \\
Compassionate Care & 0.111 & $\mathbf{0 . 1 2 3}$ \\
Ability to Stand in the Patient's Shoes & 0.137 & $\mathbf{0 . 0 5 8}$ \\
\hline
\end{tabular}

* Pearson's correlation test; Levene's test > 0.05 for all variables

Only age influenced the total El score, showing a weak positive correlation, as shown in other studies ${ }^{15,16}$. Coury et al., in a study carried out in another private medical school in the state of Minas Gerais, also observed a weak, but statistically significant, positive correlation between age and total El score and the domain Managing Others' Emotions ${ }^{15}$. Fariselli, Ghini and Freedman defended the hypothesis that El is a skill to be developed and that it can be improved over time through lived experiences, which results in an increase in its levels with age ${ }^{17}$. The low age range of the volunteers, as $93.8 \%$ was aged between 17 and 30 years old, may be the cause of the weak observed correlation.

There was no statistical difference between the total empathy score between men and women. This finding contradicts the results of many international studies on empathy 
Figure 2. Scatterplot between total emotional intelligence and empathy scores and between Managing Others' Emotions and total empathy score in the 193 volunteers

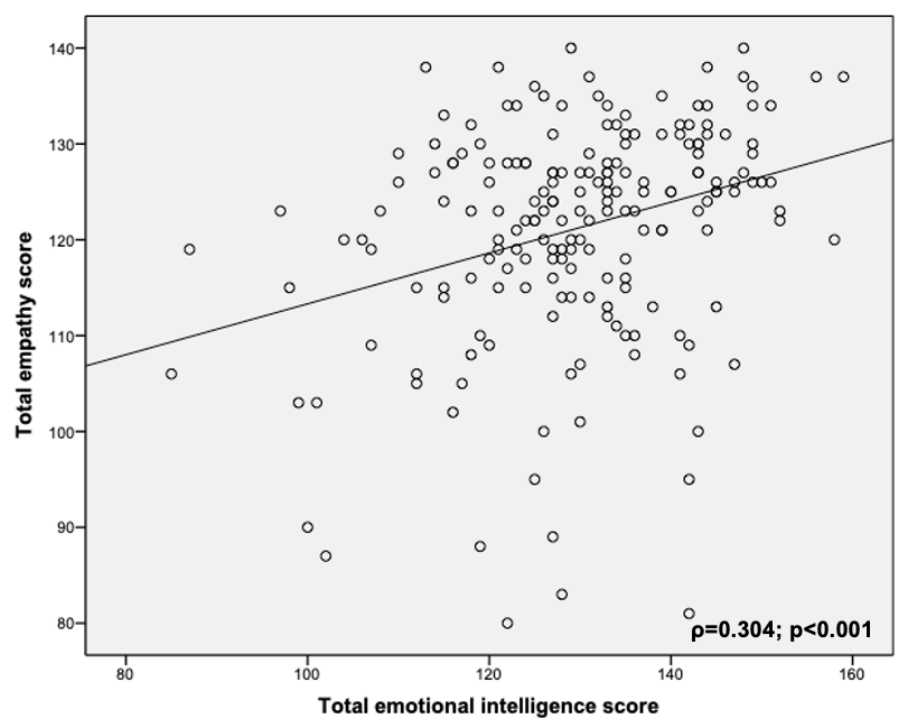

in medical students, which found higher scores in women ${ }^{6,10,18-23}$. However, the results are similar to those observed by Hong et al. in South Korea ${ }^{24}$, Di Lillo et al. in Italy ${ }^{25}$ and Rahimi-Madiseh et al. in $\operatorname{Iran}^{26}$, who did not observe any difference between empathy and gender. Of the two studies carried out in Brazil, one showed a higher empathy score in women ${ }^{27}$ and the other observed similar values between women and men $^{3}$.

Parental schooling level significantly influenced the total empathy score, with the highest scores found in students whose parents did not have a higher education degree $\left(\mathrm{p}_{\text {adjusted }}\right.$ $=0.038$ ). Perhaps students born to parents who had fewer opportunities to study might feel closer to and have more intuitive identification with the patients they care for, who may be more "similar" to their own parents.

There was no association between the program semester and the levels of $\mathrm{El}$, as in the study by Coury et al. in a population similar to the present one ${ }^{15}$. Contrary to the expectations, students attending more advanced semesters showed higher levels of empathy $\left(p_{\text {adjusted }}=0.013\right)$. Studies on empathy carried out in the United States observed its reduction throughout the medical program ${ }^{8,19,28,29}$. On the other hand, a study carried out in Japan by Kataoka et al. $^{30}$ and a study carried out in Portugal by Magalhães et al. ${ }^{21}$ observed an increase in empathy throughout the medical program. The authors indicated that empathy is strongly influenced by cultural factors and that, perhaps, it is not possible to generalize its behavior throughout the medical program in different countries ${ }^{7,21,30}$. In relation to this observation, some characteristics of the assessed program should be highlighted. Since the first semester, students have classes with professors who are specialized in Family and Community Medicine, who emphasize issues related to empathy

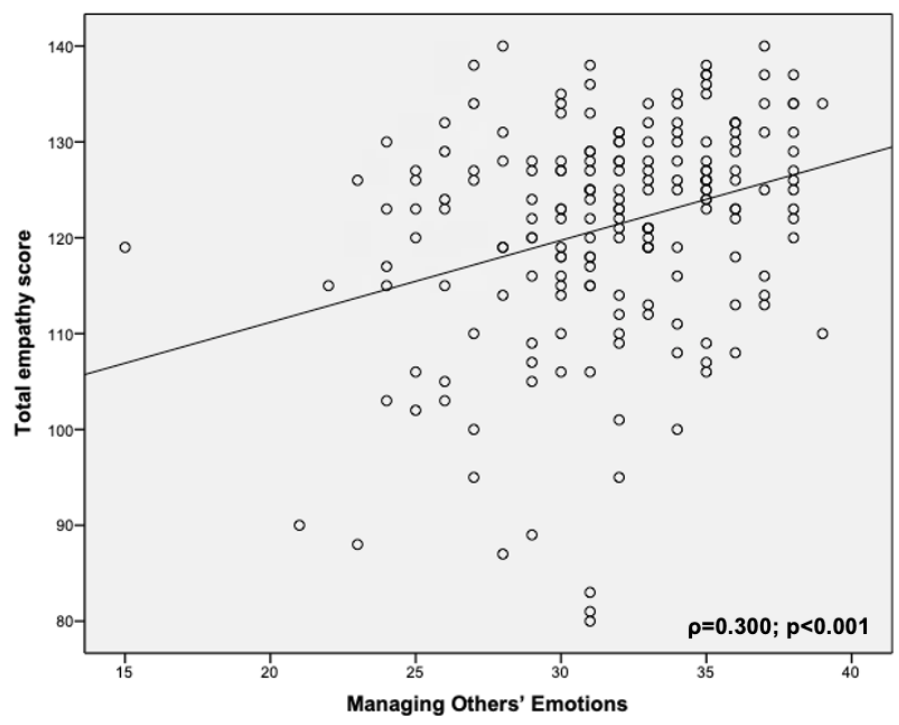

and the doctor-patient relationship during the program, which can stimulate the development of empathy. Moreover, in more advanced semesters, there is a mandatory course focused on medical psychology, which uses psychodrama techniques to put the students in the patients' place, aiming at developing communication skills and more humanized attitudes ${ }^{31}$, which can also positively influence empathy development. It should be noted, however, that at the time of the study, this medical program did not yet have supervised internship, a time when the greatest reduction in empathy levels may occur ${ }^{28}$. Therefore, despite the good results observed, one does not know how the empathy behavior will be at the end of medical program.

This finding indicates the possibility of making the medical student capable of becoming more empathic, despite all the difficulties met along the way, such as stressful factors in medical education and negative examples that these students find in the academic and clinical work environment. It reinforces that empathy is a skill that can be developed, improved, taught and must be one of the curricular goals of medical schools that are concerned with patient-centered health care ${ }^{32}$.

There was a positive and statistically significant correlation between El and empathy. This correlation was also observed by Abe et al. in Japanese medical students, although it was a weak correlation ${ }^{6}$. Bertram et al. found a strong positive correlation between the two ${ }^{18}$. When analyzing the definitions and constructs of these two skills, it is expected that the capacity to identify and discriminate their emotions and those of others influences the capacity to understand and share other people's feelings $s^{6,9}$, as observed in this and other studies ${ }^{6,18}$. It is noteworthy the moderate positive correlations between the total scores of El and empathy and between the domain 
Managing Others' Emotions (El) observed in this study.

The main limitation of this study is its cross-sectional design, which does not show the real changes that occur with students throughout medical program. This limitation is inherent to the used design and limits the conclusions related to the program semester, as there is an implicit inference that students from the early semesters will behave like the students from more advanced semesters in the future, which is not necessarily true. Another limitation is the fact that the study was carried out in a single medical school, at a private institution, which restricts the generalization of findings to similar contexts. Moreover, this is a relatively new educational institution, whose medical program was created not long ago, with no students at the supervised internship and no students that have already graduated. It is also noteworthy that the use of self-administered questionnaires can overestimate the measures, mainly due to the effect of social desirability. As a last point, it should be considered that, although the sample represents $85.6 \%$ of the potential population, its size may not have been sufficient large to identify some associations, especially those with little effect.

Despite these limitations, no other study was identified in the national literature that assessed the association between El and empathy in medical students or other health programs, which makes it an unprecedented research. Its findings are consistent with those of the current literature and indicate that there is a significant correlation between El and empathy, two essential skills for good professional medical practice.

\section{CONCLUSION}

The results indicated a positive correlation between the global scores of El and empathy and several of their domains. Higher levels of empathy were observed in students from the more advanced semesters of the program, as well as a positive correlation between age and El. Students with parents without a high education degree showed higher levels of empathy.

The assessed population has some peculiarities, such as the undergoing a practical course under the supervision of professors specialized in Family and Community Medicine since the beginning of the program and a course that uses psychodrama. These two factors may have positively influenced the study's findings and indicate possible strategies that can be used for El and empathy training in medical programs. These findings need to be confirmed by further studies, carried out in different populations. The use of intervention or quasiexperimental studies could be an alternative to more complex and longer cohort studies in further research.
Study design (ATJ and JTNS), data collection (JTNS), data analysis (ATJ), data interpretation (ATJ and JTNS), drafting of the manuscript (ATJ and JTNS), review of the manuscript (ATJ and JTNS) and approval of the final version (ATJ and JTNS).

\section{CONFLICTS OF INTEREST}

The authors declare no conflicts of interest.

\section{SOURCES OF FUNDING}

We declare no sources of funding for this research.

\section{REFERENCES}

1. Hernandez-Vargas $\mathrm{Cl}$, Dickinsion-Bannack $\mathrm{ME}$. Importancia de la inteligencia emocional em medicina. Invest Educ Med. 2014;3:155-60.

2. Thomazi L, Moreira F, Marco MA. Avaliação da evolução da empatia em alunos do quarto ano da graduação em Medicina da Unifesp em 2012. Rev Bras Educ Med. 2014;38:87-93.

3. Paro HB, Daud-Gallotti RM, Tiberio IC, Pinto RM, Martins MA. Brazilian version of the Jefferson Scale of Empathy: psychometric properties and factor analysis. BMC Med Educ. 2012;12:73.

4. Salovey P, Mayer JD. Emotional intelligence. Imag Cogn Pers. 1990;9:185-211.

5. Arora S, Ashrafian H, Davis R, Athanasiou T, Darzi A, Sevdalis N. Emotional intelligence in medicine: a systematic review through the context of the ACGME competencies. Med Educ. 2010;44:749-64.

6. Abe K, Niwa M, Fujisaki K, Suzuki Y. Associations between emotional intelligence, empathy and personality in Japanese medical students. BMC Med Educ. 2018;18:47.

7. Hojat M. Empathy in patient care: antecedentes, development, measurement and outcome. Philadelphia: Springer; 2007.

8. Newton BW, Barber L, Clardy J, Cleveland E, O'Sullivan P. Is there hardening of the heart during medical school? Acad Med. 2008;83:244-9.

9. Austin EJ, Evans P, Magnus B, O'Hanlon K. A preliminary study of empathy, emotional intelligence and examination performance in $\mathrm{MBChB}$ students. Med Educ. 2007;41:684-9

10. Hajibabaee F, Farahani MA, Ameri Z, Salehi T, Hosseini F. The relationship between empathy and emotional intelligence among Iranian nursing students. Int J Med Educ. 2018;9:239-43.

11. Hojat $M$, LaNoue M. Exploration and confirmation of the latent variable structure of the Jefferson scale of empathy. Int J Med Educ. 2014;5:73-81.

12. Schutte NS, Malouff JM, Hall LE, Haggerty DJ, Cooper JT, Golden CJ, et al. Development and validation of a measure of emotional intelligence. Personality and Individual Differences. 1998;25:167-77.

13. Toledo Júnior A, Duca JGM, Coury MIF. Tradução e adaptação transcultural da versão brasileira do Schutte Self-Report Emotional Intelligence Test. Rev Bras Educ Med. 2018;42:109-14.

14. Cohen J. Statistical power analysis for the behavioral sciences. 2nd ed Mahwah: Lawrence Erlbaum Associates; 1988.

15. Coury MIF, Duca JGM, Toledo Júnior A. Effects of mental disorders on the emotional intelligence levels of Brazilian medical students: a single center cross-sectional study, 2017-2018. Rev Bras Educ Med. 2020;44:e088.

16. Ibrahim NK, Algethmi WA, Binshihon SM, Almahyawi RA, Alahmadi RF, Baabdullah MY. Predictors and correlations of emotional intelligence among medical students at King Abdulaziz University, Jeddah. Pak J Med Sci. 2017;33:1080-5.

17. Fariselli L, Ghini M, Freedman J. Age and emotional intelligence. Six Seconds Organization; 2008 [access in 23 oct 2019]. Available from: https://prodimages.6seconds.org/media/WP_EQ_and_Age.pdf.

18. Bertram K, Randazzo J, Alabi N, Levenson J, Doucette JT, Barbosa P. Strong

\section{AUTHORS' CONTRIBUTION}


correlations between empathy, emotional intelligence, and personality traits among podiatric medical students: A cross-sectional study. Educ Health (Abingdon) 2016;29:186-94.

19. Chen $D$, Lew R, Hershman W, Orlander J. A cross-sectional measurement of medical student empathy. J Gen Intern Med. 2007;22:1434-8.

20. Duarte MIF, Raposo MLB, Rodrigues PJFSF, Branco MC. Measuring empathy in medical students, gender differences and level of medical education: an identification of a taxonomy of students. Invest Educ Med. 2016;5:253-60.

21. Magalhães E, Salgueira AP, Costa $P$, Costa MJ. Empathy in senior year and first year medical students: a cross-sectional study. BMC Med Educ. 2011;11:52.

22. Montilva M, García M, Torres A, Puertas M, Zapata E. Empatía según la escala de Jefferson em estudiantes de Medicina $Y$ Enfermería en Venezuela. Invest Educ Med. 2015;4:223-8.

23. Basílio N, Vitorino AS, Nunes JM. Caracterização da empatia em internos de medicina geral e familiar. Rev Port Med Geral Fam. 2017;33:171-5.

24. Hong $M$, Lee $W H$, Park JH, Yoon TY, Moon DS, Lee SM, et al. Changes of empathy in medical college and medical school students: 1-year follow up study. BMC Med Educ. 2012;12:122.

25. Di Lillo M, Cicchetti A, Lo Scalzo A, Taroni F, Hojat M. The Jefferson Scale of Physician Empathy: preliminary psychometrics and group comparisons in Italian physicians. Acad Med. 2009;84:1198-202.
26. Rahimi-Madiseh M, Tavakol M, Dennick R, Nasiri J. Empathy in Iranian medical students: a preliminary psychometric analysis and differences by gender and year of medical school. Med Teach. 2010;32:e471-8.

27. Nascimento HCF, Ferreira Júnior WA, Silva AMTC, Carvalho IGM, Almeida RJ. Análise dos níveis de empatia de estudantes de Medicina. Rev Bras Educ Med. 2018;42:150-8.

28. Hojat M, Vergare MJ, Maxwell K, Brainard G, Herrine SK, Isenberg GA, et al. The devil is in the third year: a longitudinal study of erosion of empathy in medical school. Acad Med. 2009;84:1182-91.

29. Neumann M, Edelhauser F, Tauschel D, Fischer MR, Wirtz M, Woopen C, et al. Empathy decline and its reasons: a systematic review of studies with medical students and residents. Acad Med. 2011;86:996-1009.

30. Kataoka HU, Koide N, Ochi K, Hojat M, Gonnella JS. Measurement of empathy among Japanese medical students: psychometrics and score differences by gender and level of medical education. Acad Med. 2009;84:1192-7.

31. Carvalho MDS. Do encontro consigo ao encontro com seu paciente: 0 psicodrama na formação médica. Rev Bras Educ Med. 2018;26:72-83.

32. Webb AR, Young RA, Baumer JG. Emotional Intelligence and the ACGME Competencies. J Grad Med Educ. 2010;2:508-12. 